\title{
Pengaruh Keterampilan Proses Sains dalam Pembelajaran Fisika pada Matakuliah Termodinamika
}

\author{
Yuniar Alam \\ Dosen Fisika Universitas Nahdlatul Ulama Blitar, Indonesia \\ Email: yuniaralam@unublitar.ac.id
}

\begin{tabular}{l}
$\overline{\text { Tersedia Online di }}$ \\
\hline http://www.jurnal.unublitar.ac.id/ \\
index.php/briliant
\end{tabular}

Sejarah Artikel

Diterima pada 15 Juli 2019

Disetujui pada 30 Agustus 2019

Dipublikasikan pada 31 Agustus

2019 Hal. 282-288

\section{Kata Kunci:}

Keterampilan Proses Sains,

Pembelajaran, Hasil Belajar

\section{DOI:}

http://dx.doi.org/10.28926/briliant .$v 3 \mathrm{i} 4.338$

\begin{abstract}
Abstrak: Proses belajar mengajar sangat menentukan keberhasilan hasil belajar, strategi pembelajaran bergantung pada kepiawaian pengajar dalam menggunakan metode dan teknik pembelajaran. Penelitian ini bertujuan mencari pengaruh hasil belajar termodinamika menggunakan penguasaan keterampilan proses sains pada mahasiswa UNU Blitar dengan menggunakan teknik wawancara terstruktur, angket dan instrumen. Pembelajaran menggunakan keterampilan proses sain menunjukan peningkatan yang signifikan dalam mencapai hasil belajar dimana siswa lebih mudah memahami dan mengerti dalam proses pembelajaran. Teknik analisis data dalam penelitian ini menggunakan analisis statistik deskriptif. Teknik Pengumpulan data menggunakan pretest-postest dengan indicator yang sesuai dengan pembelajaran. Hasil data menunjkan bahwa keterampilan proses sain memiliki pengaruh yang signifikan untuk proses pembelajaran fisika.
\end{abstract}

\section{PENDAHULUAN}

Keterampilan proses sains memiliki bagian-bagian dalam proses seperti cara berpikir, melakukan pekerjaan, interaksi berkomunikasi, dan mengambil sikap yang merupakan kebutuhan dalam memecahakan masalah dalam kehidupan. Dalam pembelajaran sains, terutama fisika proses membangun pengetahuan sendiri bagi peserta didik amat penting. Peserta didik hanya akan mengerti dengan sungguh-sungguh dan mempunyai kompetisi dalam bidang fisika yang digeluti bila peserta didik sendiri aktif, mengolah, mencerna, dan merumuskannyadipikirannya sendiri. Keterampilan proses sains merupakan kemampuan yang medasar dalam memahami sains. Dalam proses pembelajaran peserta didik, modal dasar untuk memahami pembelajaran sains adalah keterampilan proses sains. Keterampilan proses sains merupan pembelajaran yang memberikan pengalaman belajar bagi peserta didik. Dari data yang dperoleh masih banyak pengajar belum mengoptimalkan keterampilan proses sains tingkat dasar peserta didik. Ada tujuh tahap dalam pembelajaran proses sains yaitu (1) kemampuan dalam mengamati, (2) bagaimana peserta didik merumuskan permasalahan, (3) merencanakan percobaan, (4) peserta didik melakukan percobaan (5) peserta didik menganalisa data (6) peserta didik menemukan maslah dan mulai menerapkan konsep materi dan praktek (7) peserta didik saling berkomusikasi dan bertukar pendapat (Alam, 2012). Peserta didik merupakan sasaran dari hasi belajar melalui keterampilan proses sains peserta didik mampu 
mengembangkan keterampilan dari potensi peserta didik sendiri mulai dari menemukan fakta, konsep dan teori baru. Model pembelajaran yang monoton atau berpusat pada guru akan menyebabkan pembelajaran tidak optimal. Keterampilan proses sain berperan membantu siswa dalam mengembangkan kemampuan sainsnya. Penguasaan pembelajaran fisika secara teoritis melalui keterampilan proses sains sangat menentukan kemampuan peserta didik, hal ini mengimplikasikan bahwa keterampilan proses sains yang dimiliki peserta didik memiliki hasil yang berkolerasi dengan prestasi akademik. Peserta didik mencapai pembelajaran yang optimal memelukan keterampilan proses sains. Pelatihan kemampuan mental, fisik dan kemampuaan sosial pada lingkungan merupakan keterampilan proses yang mendasar sebagai gerakan dari kemampuan. Dengan mengembangkan kemampuan dasar dengan selalu melakukan latihan-latihan maka dari waktu ke waktu akan menjadi suatu keterampilan, pendekatan keterampilan proses bagaimana memandang peserta didik seutuhnya. Penjabaran dalam memandang kegiatan belajar mengajar pengembangan pengetahuan, sikap nilai dan keterampilan.

Kreativitas merupakan bentuk dari proses pembelajaran dan menyatu pada unsur dari keterampilan proses sains tersebut. Pendekatan keterampilan proses adalah proses pembelajaran yang dirancang sedemikian rupa sehingga siswa menemukan fakta-fakta, membangun konsep-konsep dan teori-teori dengan keterampilan intelektual dan sikap ilmiah siswa sendiri. Menurut Dimyati dan Mudjiono (2010) Pendekatan keterampilan proses bukanlah tindakan instruksional yang berada diluar kemampuan peserta didik. Pengembangan dengan kemampuan-kemampuan keterampilan proses memiliki tujuan a). Keterampilan proses merupakan pendekatan yang memberikan pengertian kepada peserta didik tetang hakikatnya ilmu pengetahuan. Rasa keingintahuan peserta didik mengungkapkan fakta mengalami peningkatan dan memahami ilmu pengetahuan lebih baik. Pembelajaran keterampilan proses sains memberikan keleluasaan kepada peserta didik mengerjakan dengan llmu pengetahuan, bukan hanya mendengar dan bercerita tentang pengetahuan sains. Peserta didik akan merasa senang karena keaktifan peserta didik dan tidak menjadi pelajar yang pasif. c). Mengajarkan peserta didik pengetahuan sains dan proses pemelajaran dengan keterampilan proses sains pada pembelajaran fisika secara bersamaan.

Keterampilan proses sains menekankan pada kehidupan sehari-hari. Keberhasilan keterampilan proses sains menyelesaikan berbagai permasalahan bermanfaat bagi mahasiswa sendiri. Pembelajaran keterampilan proses sains terhadap hasil belajar menunjukan hasil bahwa terdapat perbedaan yang signifikan sebelum dan di berikan perlakuan. Berdasarkan uraian diatas sangat terlihat bahwa keterampilan proses sains dapat meningkatkan hasil belajar siswa. Peneliti menganggap bahwa perlu di lakukan penelitian mengenai keterampilan proses sain terhadap hasil belajar.

\section{METODE}

Metode penelitian yang digunakan pada penelitian ini adalah One Group Pretest-Posttest Design (Trihendradi, 2009). Metode One Group Pretest-Posttest Design merupakan desain penelitian dengan urutan pretest dan posttest. Dalam metode ini satu kelompok yang dipilih secara random. Kemudian diberi perlakuan yaitu pemberian materi dan arahan dengan keterampilan proses sains berikutnya 
dilakukan posttest untuk menguji hasil belajar setelah diberi perlakuan. Keterampilan proses sains merupakan sejumlah keterampilan yang dibentuk oleh komponen-komponen metode sains/scientific methods. Keterampilan proses (prosess-skill) sebagai proses kognitif termasuk di dalamnya juga interaksi dengan isinya (content). Langkah-langkah demikian diperlukan untuk memahami hakikat ilmu dalam sains yang diperoleh oleh para ilmuwan sebelumnya, yaitu sebagai ilmu yang terdiri dari berbagai konsep, saling berkaitan dan berkembang dari hasil suatu eksperimen dan observasi (Ramdan dan Hamidah, 2014). Keterampilan Proses merupakan keseluruhan keterampilan ilmiah yang terarah (baik kognitif maupun psikomotor) yang dapat digunakan untuk menemukan suatu konsep atau prinsip atau teori, untuk mengembangkan konsep yang telah ada sebelumnya, ataupun untuk melakukan penyangkalan terhadap suatu penemuan (falsifikasi). Keterampilan proses dasar merupakan fondasi bagi terbentuknya landasan berpikir logis. Oleh karena itu, sangat penting dimiliki dan dilatihkan bagi siswa sebelum melanjutkan ke keterampilan proses yang lebih rumit dan kompleks. Dalam pelaksanaannya keterampilan proses memiliki tujuan. Menurut Djamarah (2010) Tujuan keterampilan proses adalah mengembangkan kreativitas anak didik dalam belajar, sehingga anak didik secara aktif dapat mengembangkan dan menerapkan kemampuan-kemampuannya. Lingkup kegiatan bertolak pada kemampuan fisik dan mental yang mendasar sesuai demgan apa yang ada pada pribadi anak didik.

Menurut Tawil dan Liliasari (2014), keterampilan proses sains sangat penting untuk diimplementasikan dari sekarang, karena melihat perkembangan ilmu pengetahuan yang semakin cepat dan maju sehingga tidak mungkin lagi jika siswa hanya diajarkan secara verbal, akan tetapi siswa harus dibiasakan untuk mengembangkan ilmu, menemukan pengetahuan baru, serta dapat menemukan konsep-konsep. Keterampilan proses sains perlu dikembangkan sejak siswa menduduki sekolah dasar. Pembelajaran akan lebih menarik dan menimbulkan kesan yang positif yang akan tertanam dalam diri siswa sampai mereka beranjak dewasa dengan menggunakan keterampilan proses sains. Menurut Lela, Ani, dan Asep (2017) Selain itu keterampilan proses sains dapat mengembangkan pemahaman siswa pada materi yang sedang dipelajarinya, serta dapat menumbuhkan dan mengembangkan sikap dan nilai yang dituntut, sehingga siswa akan aktif pada proses pembelajaran berlangsung. Denan menggunakan keterampilan proses sains pembelajaran akan lebih menarik dan menyenangkan, serta dapat memberikan banyak hal yang positif setelah memelajari materi yang telah diajarkan. Pembentukan keterampilan dalam memperoleh pengetahuan merupakan salah satu penekanan dalam pembelajaran sains oleh karena itu penilaian terhadap keterampilan proses siswa harus dilakukan terhadap semua keterampilan proses sains baik secara parsial maupun secara utuh. Penilaian merupakan tahapan penting dalam proses pembelajaran. Penilaian dalam pembelajaran sains dapat dimaknai sebagai pembawa konten, proses sains dan sikap ilmiah secara bersama-sama. Penilaian dilakukan terutama untuk menilai kemajuan siswa dalam pencapaian keterampilan proses sains. Pengumpulan data dilakukan dengan menggunakan lembar pengumpulan data berbentuk tabel yang diperoleh dari skor untuk keterampilan proses sains serta skor ujian (observasi) untuk hasil belajar.

284 BRILIANT: Jurnal Riset dan Konseptual Volume 4 Nomor 3, Agustus 2019 


\section{HASIL DAN PEMBAHASAN}

Tahap perencanaan, peneliti menyiapan instrument pembelajaran berupa RPS dan RPP. Lembar observasi yang akan dicentang oleh observer sesuai dengan proses pembelajaran yang berlangsung di kelas instrument pengamatan yang meliputi untuk menuliskan segala hal penting atau yang ditekankan selama proses pembelajaran, wawancara kepada mahasiswa tentang pendapat mereka terhadap pembelajaran menggunakan keterampilan proses sains dan perubahannya, dan mempersiapkan tes di akhir pertemuan untuk mengukur peningkatan kemampuan mahasiswa setelah diterapkannya pembelajaran keterampilan proses sains. Kegiatan pembelajaran menerapkan pembelajaran keterampilan proses sains dengan hasil belajar mahasiswa mengerjakan patest berupa soal sesuai materi yang diberikan. Pengumpulan data disajikan pada Tabel 1.

Table 1 Data keterampilan Proses Sains sebelum diberikan perlakuan

\begin{tabular}{|c|l|c|}
\hline No & \multicolumn{1}{|c|}{ Parameter } & Pretest \\
\hline 1 & Jumlah Siswa & 12 \\
\hline 2 & Rata-rata & 67 \\
\hline 3 & Nilai Tertinggi & 80 \\
\hline 4 & Nilai Terendah & 40 \\
\hline
\end{tabular}

Tabel 2 Data Hasil Belajar

\begin{tabular}{|c|l|c|}
\hline No & \multicolumn{1}{|c|}{ Parameter } & Posttest \\
\hline 1 & Jumlah Siswa & 12 \\
\hline 2 & Rata-rata & 72 \\
\hline 3 & Nilai Tertinggi & 100 \\
\hline 4 & Nilai Terendah & 40 \\
\hline
\end{tabular}

Metode yang digunakan selama ini adalah teacher center yang menunjukan bahwa pembelajaran fisika khususnya pada mata kuliah Termodimaika masih sangat monoton dengan dosen sebagai sumber belajar yang menyebabkan mahasiswa malas mengikuti pembelajaran. Data hasil penelitian adalah keterampilan proses sains melalui tes di akhir perkuliahan.

Pengujian terhadap data yang diperoleh sebelumnya harus dilakukan uji normalitas terlebih dahulu. Uji normalitas dilakukan dengan tujuan menilai data variable apakah data tersebut berdistribusi normal atau tidak. Hasil uji normalitas tersebut di tampilkan pada table 3 .

Tabel 3 Hasil Uji Normalitas Data Keterampilan Proses Sains dan Hasil Belajar

\begin{tabular}{|l|c|c|}
\hline \multicolumn{1}{|c|}{ Data } & $\begin{array}{c}\text { Asymp. Sig } \\
\text { (2-tailed) }\end{array}$ & Keterangan \\
\hline Keterampilan Proses Sains & 0.706 & Normal \\
\hline Hasil Belajar Siswa & 0.536 & Normal \\
\hline
\end{tabular}

Berdasarkan Tabel 3 dapat diketahui bahwa nilai Asymp.Sig dari data keterampilan proses sains dan hasil belajar diperoleh lebih dari 0,025 artinya data keterampilan proses sains dan hasil belajar siswa berdistribusi normal. Setelah didapatkan data yang berdistribusi normal dan linear, maka dapat dilakukan uji hipotesis menggunakan uji regresi linear sederhana untuk mengetahui arah 
hubungan antara variabel bebas dengan variabel terikat apakah positif atau negatif, dapat dilihat pada Tabel 4.

Tabel 4. Hasil Uji Regresi Data Keterampilan Proses sains dan Hasil Belajar

\begin{tabular}{|c|c|c|c|c|c|c|c|}
\hline \multicolumn{8}{|l|}{ Coefficients $^{\mathrm{a}}$} \\
\hline \multirow[t]{2}{*}{ Model } & \multicolumn{2}{|c|}{$\begin{array}{l}\text { Unstandardized } \\
\text { Coefficients }\end{array}$} & \multirow{2}{*}{$\begin{array}{c}\text { Standardized } \\
\text { Coefficients } \\
\text { Beta }\end{array}$} & \multirow{2}{*}{$\mathrm{T}$} & \multirow{2}{*}{ Sig. } & \multicolumn{2}{|c|}{$\begin{array}{l}95.0 \% \text { Confidence } \\
\text { Interval for B }\end{array}$} \\
\hline & B & $\begin{array}{l}\text { Std. } \\
\text { Error }\end{array}$ & & & & $\begin{array}{l}\text { Lower } \\
\text { Bound }\end{array}$ & $\begin{array}{l}\text { Upper } \\
\text { Bound }\end{array}$ \\
\hline 1 (Constant) & 32,15 & 14,75 & & $\begin{array}{c}2,1 \\
7\end{array}$ & 0,03 & 2,06 & 62,24 \\
\hline $\mathrm{kps}$ & 0,59 & 0,21 & 0,44 & $\begin{array}{c}2,7 \\
5\end{array}$ & 0,01 & 0,15 & 1,03 \\
\hline
\end{tabular}

a. Dependent Variable: hasilbelajar

Dari tabel tersebut dapat diperoleh persamaan regresi sebagai berikut:

$\mathrm{Y}^{\prime}=\mathrm{a}+\mathrm{bX}$

$Y^{\prime}=32,155+0,593 \mathrm{X}$

Dengan

$Y^{\prime} \quad$ : Hasil Belajar

$\mathrm{X} \quad$ : Keterampilan Proses Sains

Berdasarkan Tabel 4 koefisien regresi yang dihasilkan bernilai positif, yang artinya $\mathrm{H}_{0}$ ditolak dan $\mathrm{H}_{1}$ diterima. Pada uji regresi juga diperoleh Fhitung yang memaparkan tentang uji ke-linearan, dapat dilihat pada Tabel 5.

Tabel 5. Hasil $F_{\text {hitung }}$ Data Keterampilan Proses Sains dan Hasil Belajar Siswa

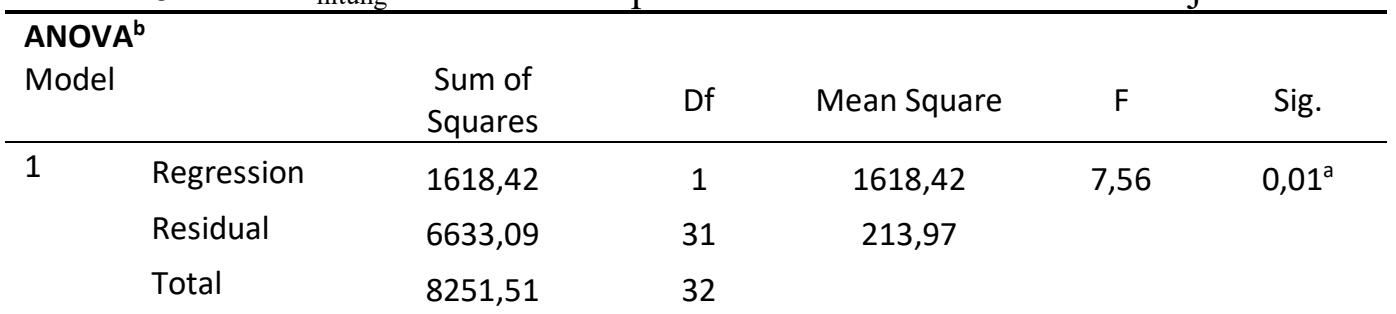

a. Predictors: (Constant), keterampilan proses sains

b. Dependent Variable: hasilbelajar

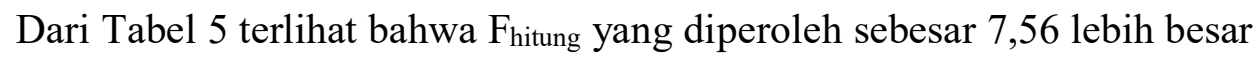

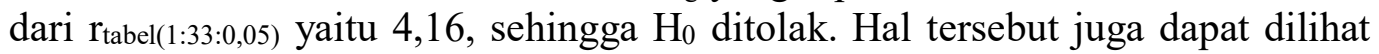
pada hasil yang menunjukkan nilai Sig. lebih kecil dari 0,05 yaitu 0,01 yang berarti $\mathrm{H}_{0}$ ditolak. Berdasarkan hasil dari semua pengujian untuk hipotesis pertama yang menunjukkan bahwa $\mathrm{H}_{0}$ ditolak dan $\mathrm{H}_{1}$ diterima, maka dapat dikatakan bahwa terdapat pengaruh linear yang positif dan signifikan antara keterampilan proses ilmiah terhadap hasil belajar. 
Dari uji hipotesis yang telah dilakukan dapat dilihat bahwa $t_{\text {hitung }}>t_{\text {tabel }}$ maka $\mathrm{H}_{0}$ ditolak, artinya ada pengaruh keterampilan proses sains terhadap hasil belajar. Bentuk pengaruh keterampilan proses sains terhadap hasil belajar dinyatakan dengan persamaan regresi linier sederhana $\mathrm{Y}^{\prime}=32.155+0.593 \mathrm{X}$. Jika nilai keterampilan proses sains mengalami kenaikan sebesar 1, maka hasil belajar (Y') dapat diramalkan sebesar 30,81. Semakin tinggi keterampilan proses sains maka semakin meningkatkan hasil belajar. Hal ini dimungkinkan karena keterampilan proses sains digunakan sebagai modal untuk memecahkan masalah dalam pembelajaran. Kontribusi keterampilan proses sains terhadap hasil belajar sebesar 22\%. Pengaruh keterampilan proses sains terhadap hasil belajar diperoleh dari analisis skor keterampilan proses sains terhadap skor total hasil belajar. Berdasarkan hasil analisis pada uji regresi linier sederhana terlihat bahwa koefisien regresi keterampilan proses sains terhadap hasil belajar bernilai positif artinya ada pengaruh yang kuat keterampilan proses sains terhadap hasil belajar siswa, maka dapat di-simpulkan bahwa terdapat hubungan yang positif dan signifikan antara keterampilan proses sains dan hasil belajar.

Peserta didik diajak untuk berani menggunakan keterampilan proses sains dalam mengungkapkan suatu pendapat baik di depan umum atau tidak. Artinya selain menumbuhkan rasa ingin tahu dalam pembelajaran juga menumbuhkan mental peserta didik sendiri dapat mengungkapkan pengetahuannya melalui diskusi kelas dengan saling bertukar pendapat dan mengambil kesimpulan dari suatu permasalahan fisika. Dengan penjelasan lisan pada saat proses pembelajaran dengan menggunakan metode diskusi kelompok belum cukup untuk membuat peserta didik membentuk pengertian dengan baik dan sempurna, sehingga hasil belajar yang diperoleh peserta didik dengan pembelajaran konvensional belum dapat mengunggali hasil belajar. Dilihat dari hasil yang diperoleh bahwa hasil belajar peserta didik cenderung pada kategori baik, hal ini menunjukkan adanya faktor lain yang mempengaruhi peningkatan hasil belajar peserta didik selain dari keterampilan proses sains, misalnya adanya beberapa siswa yang masih ragu-ragu dan malu untuk mengeluarkan pendapatnya.

Keterampilan proses sains merupakan sesuatu yang baru bagi peserta didik dan keterampilan proses sains juga perlu waktu yang lama untuk memahaminya. Dalam penerapannya keterampilan proses sains ini memberikan kesempatan kepada peserta didik untuk mengemukakan pendapatnya dalam memecahkan masalah baik individu maupun kelompok. Namun jika peserta didik diberi kesempatan untuk mengemukakan pendapatnya, hal itu akan mengakibatkan diskusi kelas yang membuat peserta didik mencari tahu dan menemukan sendiri konsep fisika yang dipelajari. Sehingga hasil belajar peserta didik dapat meningkat dengan pengalaman langsung yang dirasakan oleh peserta didik itu sendiri. Dengan hal tersebut juga akan peserta didik membantu meningkatkan rasa ingin tahu peserta didik karena setiap pendapat siswa akan diberi nilai meskipun pendapatnya terkadang terbalik dalam tulisan dan ucapan.

Berdasarkan penelitian yang telah dilakukan peneliti, dapat dinyatakan bahwa kemampuan keterampilan proses sains dalam pembelajaran dapat melatih peserta didik mengkaji sendiri pola pikirnya untuk menciptakan pernyataan (ungkapan) pengetahuan dari bahasa sendiri sesuai dengan materi yang diajarkan oleh dosen sehingga peserta didik akan lebih paham dengan inti pokok dari materi tersebut. Berdasarkan penelitian peserta didik pun akan lebih berani 
menyampaikan pendapat dan pertanyaan dari masalah yang dihadapi dalam fisika sesuai dengan apa yang diketahuinya.

Hal ini jelas bahwa keterampilan proses sains sangat penting dalam pembelajaran fisika agar peserta didik mampu mengaplikasikan pendapatnya sendiri dengan pengetahuan dan kreatifitasnya dalam mengemukakan pendapat dan menyimpulkan suatu permasalahan. Sehingga dapat dikatakan bahwa keterampilan proses sains berpengaruh terhadap hasil belajar.

\section{KESIMPULAN}

Pembelajaran keterampilan proses sains dapat meningkatkan hasil belajar pada mahasiswa Program Studi Fisika Universitas Nahdlatul Ulama Blitar. Dengan menggunakan pembelajaran ini, mahasiswa lebih mudah dalam memahami pembelajaran fisika matakuliah Termodinamika. Terdapat pengaruh penggunaan pembelajaran keterampilan proses sains terhadap hasil belajar. Semakin tinggi keterampilan proses sains maka semakin meningkatkan hasil belajar tidak berlaku sebaliknya.

\section{SARAN}

Saran yang pertama kepada dosen pengajar diharapkan menggunakan metode mengajar yang inovatif salah satunya pembelajaran keterampilan proses sains ini untuk mengajar matakuliah termodinamika. Saran kedua untuk peserta didik diharapkan untuk tetap aktif dan bersemangat dalam mempelajari fisika sebagai bahasa asing sampai menguasainya. Selain itu, mereka dapat menggunakan langkah-langkah yang terdapat pada langkah keterampilan untuk membantu dalam pemahaman tingkat dasar keterampilan proses sains.

\section{DAFTAR RUJUKAN}

Alam, Yuniar. (2012). Pengaruh Keterampilan Proses Sains pada Pembelajaran Kooperatif Tipe Search, Solve, Create, and Share (SSCS) Terhadap Hasil Belajar Fisika. Skripsi. Lampung: Universitas Lampung.

Ramdan, Sahri dan Hamidah, Ida. (2015). Peningkatan Keterampilan Proses Sains Siswa Smp Melalui Penerapan Levels Of Inquiry Dalam Pembelajaran IPA Terpadu. Journal EDUSAINS, Vol. 7 No 02:106-113

Rahayu, Ai Hayati dan Anggraeni, Poppy. 2017. Analisis Profil Keterampilan Proses Sains Siswa Sekolah Dasar Di Kabupaten Sumedang. Jurnal Pesona Dasar, Vol. 5 No 2: 22- 33

Gusdiantini, dkk. (2017). Pengembangan Keterampilan Proses Sains Siswa Kelas V Pada Materi Gaya Gesek Melalui Pembelajaran Kontekstual. Jurnal Pena Ilmiah: Vol 2 No 1:651-660

Dimyati dan Mudjiono. (2010). Belajar dan Pembelajaran. Rineka Cipta. Jakarta.

Djamarah, Syaiful Bahri. (2010). Guru Dan Anak Didik Dalam Interaksi Edukatif. Rineka Cipta. Jakarta.

Suparno, Paul. (2013). Metodelogi Pembelajaran Fisika, Kontruktivistik dan Menyenangkan. Yogyakarta: Universitas Sanata Dharma.

Tawil \& Liliasari. (2014). Keterampilan-keterampilan sains dan implementasinya dalam pembelajaran IPA. Makasar: Badan Penerbit UNM.

Trihendradi, Cornelius. (2009). Step by step SPSS 16 Analisis Data Statistik. Andi Yogyakarta. Yogyakarta. 